Vol. 4, No. 1, Juni 2020, hal. 22-38

ISSN 2598-3245 (Print), ISSN 2598-3288 (Online)

DOI: http://doi.org/10.31961/eltikom.v4i1.157

Tersedia online di http://eltikom.poliban.ac.id

\title{
PENGEMBANGAN MEKANISME CHANGE DETECTION UNTUK EFISIENSI ENERGI PADA WIFI-BASED INDOOR POSITIONING SYSTEM
}

\author{
Ade Hendi, Waskitho Wibisono, dan Ary Mazaharudin Shiddiqi \\ Departemen Informatika, Institut Teknologi Sepuluh Nopember, Surabaya, Indonesia \\ e-mail: hendi.ade@gmail.com,waswib@if.its.ac.id, ary.shiddiqi@if.its.ac.id
}

Diterima 31 Desember 2019 - Direvisi 7 Januari 2020 - Disetujui 11 Jjanuari 2020

\begin{abstract}
The development of the change detection mechanism has a vital role in the Indoor Positioning System (IPS). In IPS technology, a lot of battery power will be used because the WiFi scanning process runs continuously. The WiFi scanning process sends data from the client to the server continuously, sometimes providing the same and repeatable information to the user. Information sent redundantly can have an impact on high energy consumption. In this paper, the researchers developed a repair mechanism with change detection to save energy in an adaptive sampling of the strength of the WiFi signal with the accelerometer as a trigger for the adaptive process. The change detection mechanism that is done is measuring the signal strength on the accelerometer by determining the silent zone. Silent Zone is the range of values obtained when the accelerometer is at rest. If it is known that the signal strength value on the Accelerometer exceeds the value of the silent zone, the user is identified in a mobile condition, and the WiFi scanning process will automatically run. Change detection with Bluetooth has the same process using an accelerometer. The algorithm we propose can produce a battery-saving of $4.384 \%$ for scanning with change detection using an accelerometer and $2.666 \%$ for change detection using Bluetooth.
\end{abstract}

Keywords: adaptive sampling, accelerometer, bluetooth, change detection, indoor positioning system.

\begin{abstract}
ABSTRAK
Pengembangan mekanisme change detection mempunyai peranan penting terhadap Indoor Positioning System (IPS). Namun permasalahan yang masih umum dijumpai adalah konsumsi energi yang tinggi, karena proses WiFi scanning berjalan secara terus menerus. Proses WiFi scanning mengirimkan data dari klien ke server secara terus menerus, terkadang memberikan informasi yang sama dan berulang kepada user. Informasi yang dikirim secara redundansi bisa berdampak pada konsumsi energi yang tinggi. Paper ini mengusulkan mekanisme perbaikan dengan change detection untuk penghematan energi dalam melakukan sampling secara adaptif pada kekuatan sinyal WiFi dengan accelerometer sebagai trigger. Mekanisme change detection yang dilakukan adalah mengukur kekuatan sinyal pada accelerometer dengan menentukan silent zone. Silent Zone merupakan rentang nilai yang didapatkan ketika accelerometer dalam kondisi diam. Apabila diketahui nilai kekuatan sinyal pada accelerometer melebihi nilai silent zone, maka diidentifikasi user dalam kondisi bergerak dan secara otomatis proses WiFi scanning akan berjalan. Change detection dengan Bluetooth mempunyai proses yang sama dengan menggunakan accelerometer. Algoritma yang diusulkan dapat menghasilkan penghematan daya baterai sebesar 4,384\% untuk scanning dengan change detection menggunakan accelerometer dan 2,666\% untuk change detection menggunakan Bluetooth.
\end{abstract}

Kata Kunci: akselerometer, bluetooth, deteksi perubahan, indoor positioning system, pengambilan sampel adaptif.

\section{Pendahuluan}

$\mathrm{T}$ TeKnologi Indoor Positioning System (IPS) merupakan sebuah layanan informasi pelacakan untuk menemukan objek khusus dalam ruangan. Aplikasi yang berjalan dalam perangkat bergerak mengkonsumsi cukup banyak daya baterai. Hal ini disebabkan karena proses scanning yang terus menerus membutuhkan daya yang cukup banyak sehingga mengurangi daya baterai secara 


\section{Jurnal ELTIKOM : Jurnal Teknik Elektro, Teknologi Informasi dan Komputer}

runtime, misalnya perangkat bergerak mengkonsumsi lebih dari $40 \%$ daya baterai yang keseluruhannya dipergunakan pada fasilitas WiFi [1]. Teknologi sebelumnya layanan informasi pelacakan menggunakan Global Positioning System (GPS) yang merupakan sensor dominan untuk layanan informasi pelacakan suatu objek diluar ruangan. Sedangkan Pemakaian GPS dalam suatu ruangan memiliki kendala karena ketersediaan jalur Line-of-Sight [2]. Ketersediaan jalur Line-of-Sight (LOS) yang rendah menjadi kendala dalam menemukan antara pemancar dan penerima sinyal, hilangnya LOS diantara perangkat seluler dan satelit dapat membuat kinerja GPS kurang maksimal di dalam ruangan [3].

Dalam proses scanning sinyal WiFi berlaku secara terus menerus, sehingga ketika proses sampling pada posisi yang sama akan terjadi redundansi data dan penggunaan energi baterai yang tidak efisien. Untuk mengatasi hal tersebut dibutuhkan suatu trigger untuk mengatur proses scanning yaitu adaptive sampling [4].

Pengambilan sampel secara adaptif adalah salah satu cara yang paling komprehensif dalam pengumpulan data. Dengan menyesuaikan frekuensi pengambilan sampel kekuatan sinyal pada WiFi dari waktu ke waktu, untuk beradaptasi terhadap perubahan yang dihasilkan dari dinamika Indoor positioning system (IPS). Komponen lain untuk melakukan sampling secara adaptif adalah aktivitas pada tingkat user di mana pada kondisi sedang proses WiFi scanning. Proses tersebut menunjukkan bahwa sebelum melakukan proses scanning, sistem harus mengecek terlebih dahulu jika user bergerak secara signifikan dari posisi yang sudah diketahui sebelumnya. Proses pergerakan user dapat dideteksi dengan mengimplementasikan Bluetooth [5]. Deteksi gerak menggunakan Bluetooth ini mempunyai dua keuntungan, yang pertama detektor gerak dapat dipasang secara flexible dan tertutup dari orang-orang. Keuntungan kedua Bluetooth bekerja dengan menggunakan daya baterai rendah. Di samping hal tersebut sangat mudah dalam pemeliharaan system deteksi gerak menggunakan Bluetooth [5]. Ilustrasi transmisi sinyal Bluetooth seperti pada Gambar 1. Penelitian sebelumnya untuk mendeteksi gerak menggunakan accelerometer untuk menciptakan sistem orientasi pengenalan aktivitas [6]. Deteksi gerakan manusia dengan studi mempertimbangkan unit sensor accelerometer yang dapat dipakai dan diletakkan pada bagian tubuh dengan orientasi tertentu [7, 8].

Saat ini penelitian tentang topik terkait telah banyak dikembangkan. Studi penelitian $[9,10,11,12]$ fokus pada efisiensi baterai dengan layanan informasi pelacakan secara adaptif untuk mengurangi penggunaan energi baterai yang tinggi karena disebabkan oleh penggunaan perangkat WiFi. Untuk mengkarakterisasikan penggunaan energi baterai, permintaan energi perangkat seluler ditentukan dari perangkat keras dan perangkat lunak [13].

Masalah yang diangkat dalam penelitian ini adalah cara melakukan sampling kekuatan sinyal pada WiFi secara adaptif untuk penghematan energi dalam Indoor positioning system (IPS). Penelitian telah mengarah pada penciptaan suatu sistem yang sadar akan energi yang dirancang bertujuan mengurangi konsumsi energi pada aplikasi IPS [14]. Pada penelitian terkait yang lain juga meneliti scanning kekuatan sinyal secara adaptif, untuk tujuan penghematan energi dengan sistem pengenalan aktivitas yang menggunakan sistem lokasi berbasis WiFi yang dikombinasikan dengan accelerometer untuk identifikasi gerak [15].

Pada penelitian ini, mekanisme change detection dengan pengambilan sampel secara adaptif menggunakan accelerometer sebagai trigger diusulkan untuk meningkatkan efisiensi energi. Change detection merupakan proses penting [16] sebagai analisa untuk mengukur rentang nilai pada accelerometer sebagai silent zone [17].

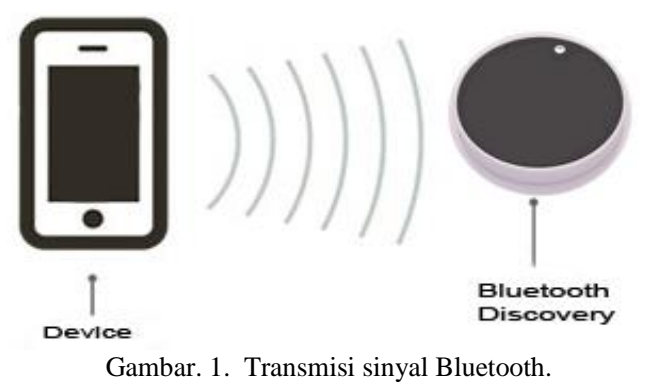




\section{Metode PenElitian}

Fokus penelitian ini adalah penghematan pada daya baterai di mana proses scanning kekuatan sinyal WiFi akan diproses sesuai dengan ada tidaknya perubahan nilai pada accelerometer sebagai change detection. Pengurangan frekuensi scanning bertujuan untuk mengurangi konsumsi daya baterai. Prediksi ada atau tidaknya perubahan aktivitas pada posisi yang terjadi pada user dilihat dari ada atau tidaknya perubahan nilai yang dihasilkan dari accelerometer. Secara umum, perubahan dikenal sebagai perpindahan dari satu kondisi ke kondisi lainnya [18]. Pemilihan model yang tepat untuk proses identifikasi dan perkiraan terhadap parameter, digunakan untuk mendeteksi dengan menggunakan nilainilai kriteria merupakan suatu proses yang menyiratkan suatu perubahan berdasarkan nilai varian [19]. Bidang penting dalam analisis data adalah segmentasi data deret waktu untuk mengidentifikasi aktivitas dengan menganalisis kinerja algoritma change detection dalam segmentasi data accelerometer [20].

\section{A. Change Detection}

Change detection merupakan proses penting teknik pemrosesan data, yang disediakan terutama oleh pengukuran, yang merupakan elemen kunci dari pemantauan otomatis [21]. Change detection dalam aliran data telah dipelajari secara luas karena potensinya yang luas dalam semua bidang ilmu pengetahuan dan teknologi, misalnya, pemantauan kondisi medis, dan kontrol lalu lintas jaringan [22]. Pada penelitian lain menjelaskan change detection merupakan suatu proses dalam memprediksi adanya suatu perubahan nilai tertentu pada sekumpulan data. Tujuan dari Prediksi change detection adalah untuk memprediksi apakah adanya suatu perubahan dari satu proses kejadian ke proses kejadian yang lain dan seberapa besar perubahannya tersebut, hal ini dapat dijadikan sebagai indikator untuk trigger dari perubahan itu [23].

Perubahan dapat dideteksi dengan menggunakan alur silent - movement mode. Pada alur silent - movement mode terdapat sebuah rentang nilai yang disebut silent zone, yang mana rentang nilai tersebut merupakan rentang toleransi atas noise pada data [17].

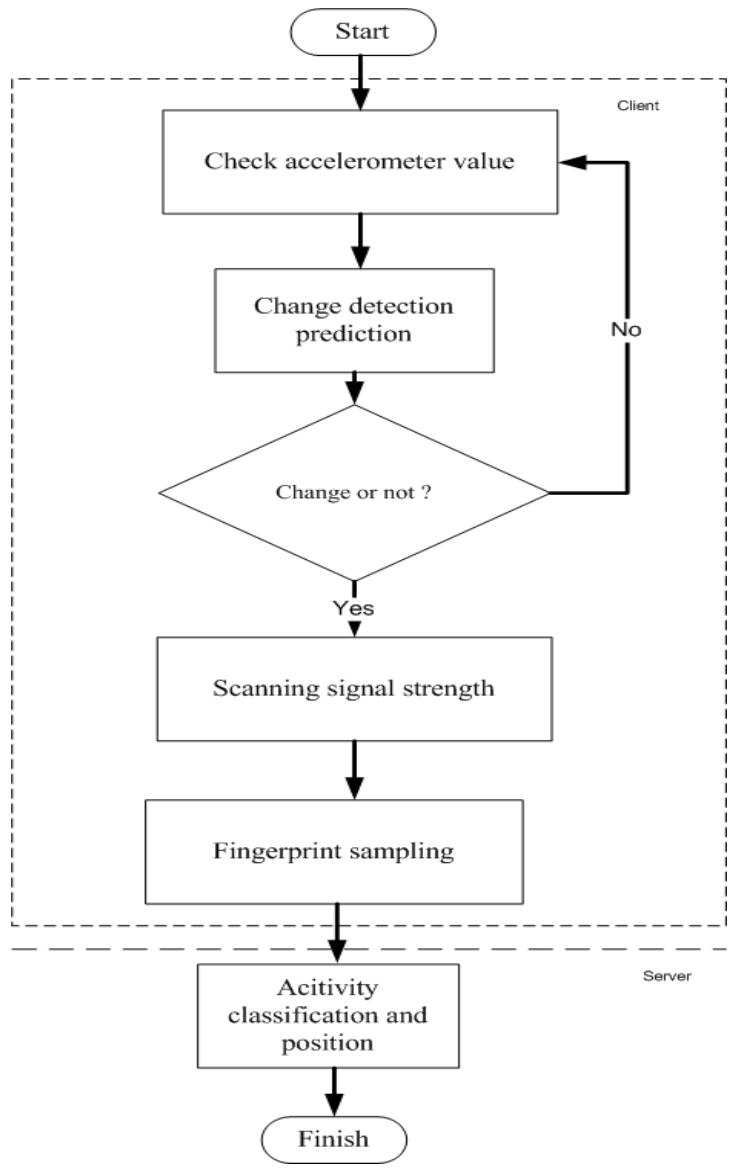

Gambar. 2. Flowchart dari metode yang diusulkan.

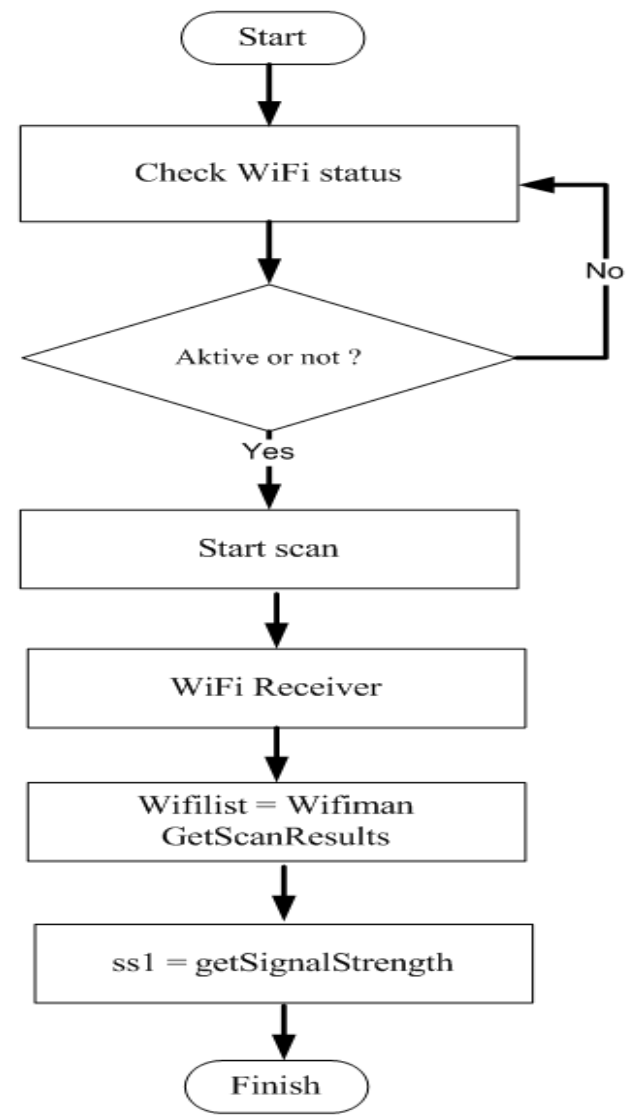

Gambar. 3. Flowchart scanning kekuatan sinyal WiFi. 


\section{Jurnal ELTIKOM : Jurnal Teknik Elektro, Teknologi Informasi dan Komputer}

Keterangan pada Gambar 3 menjelaskan bahwa untuk memulai proses scanning sinyal WiFi yang pertama kali dilakukan adalah mengecek terlebih dahulu perangkat WiFi pada Smartphone, apakah sedang aktif atau tidak. Apabila tidak aktif, maka perangkat WiFi diaktifkan. Kemudian informasi kekuatan sinyal yang dihasilkan oleh WiFi ditangkap oleh WiFi receiver kemudian disimpan pada wifiList variable selanjutnya kekuatan sinyal WiFi ditampilkan pada variable ss1 yang merupakan hasil informasi dari proses scanning sinyal WiFi.

Penjelasan alur dari Gambar 2 adalah dalam proses scanning sinyal WiFi berlaku secara terus menerus, sehingga ketika proses sampling pada posisi yang sama akan terjadi redundansi data. Untuk mengatasi hal tersebut dibutuhkan suatu trigger untuk mengatur proses scanning yaitu change detection. Sistem akan mengecek kondisi nilai pada accelerometer pertama kali, alasan penggunaannya karena sudah tertanam pada Smartphone tanpa perangkat tambahan [24], kemudian change detection akan mendeteksi apakah ada suatu perubahan nilai.

Jika change detection mendeteksi suatu perubahan [25], maka sistem akan melakukan proses scanning signal strength dari WiFi, dan sebaliknya tidak dilakukan proses scanning. Proses selanjutnya adalah melakukan sampling secara adaptif terhadap kekuatan sinyal WiFi pada client. Sistem pada server akan melakukan proses klasifikasi dan melakukan update posisi berupa informasi koordinat yang akan ditampilkan berupa map posisi kepada user.

\section{B. Silent Zone}

Silent zone merupakan konsep di mana rentang nilai pada alur silent - movement mode, yang menentukan suatu kondisi dalam keadaan benar-benar tidak bergerak [17]. Berikut contoh data dengan simulasi menggunakan silent zone. Setelah dilakukan pengambilan data selama 10 kali percobaan dengan 10 raw data, maka didapatkan total sebanyak 100 raw data, seperti pada Tabel 1.

TABEL 1

RAW DATA BLUETOOTH

\begin{tabular}{lcccccccccc}
\hline \hline & $\mathrm{I}=1$ & $\mathrm{I}=2$ & $\mathrm{I}=3$ & $\mathrm{I}=4$ & $\mathrm{I}=5$ & $\mathrm{I}=6$ & $\mathrm{I}=7$ & $\mathrm{I}=8$ & $\mathrm{I}=9$ & $\mathrm{I}=10$ \\
\hline Percobaan1 & -51 & -48 & -51 & -48 & -52 & -50 & -52 & -48 & -54 & -48 \\
Percobaan2 & -52 & -47 & -53 & -48 & -50 & -46 & -50 & -47 & -52 & -49 \\
Percobaan3 & -61 & -65 & -73 & -69 & -71 & -66 & -61 & -62 & -65 & -64 \\
Percobaan4 & -65 & -68 & -68 & -67 & -70 & -63 & -60 & -66 & -69 & -70 \\
Percobaan5 & -64 & -65 & -60 & -62 & -63 & -59 & -62 & -63 & -64 & -59 \\
Percobaan6 & -63 & -60 & -63 & -60 & -64 & -58 & -63 & -63 & -62 & -63 \\
Percobaan7 & -57 & -58 & -63 & -61 & -62 & -55 & -60 & -57 & -59 & -61 \\
Percobaan8 & -52 & -52 & -56 & -53 & -51 & -52 & -55 & -55 & -50 & -52 \\
Percobaan9 & -84 & -77 & -81 & -74 & -77 & -76 & -77 & -76 & -81 & -79 \\
Percobaan10 & -76 & -78 & -75 & -77 & -74 & -79 & -78 & -74 & -82 & -75 \\
\hline \hline
\end{tabular}

Tabel 1 menunjukkan untuk melakukan Percobaan 1, kekuatan sinyal Bluetooth dicatat sebanyak 10 kali dari $i=1$ sampai dengan $i=10$ dengan masing-masing interval pencatatan 4 detik dan dilakukan 10 kali percobaan. Semua data percobaan pada Tabel 1 akan dilakukan training dengan cara mengambil nilai selisih perubahan percepatannya dari nilai selisih tersebut ditentukan nilai absolute dengan menggunakan Persamaan 1.

$$
\text { Difference }=\left|X_{i+1}-X_{i}\right|
$$

di mana $X$ adalah data dan $i$ merupakan index dari data ke $i$. 


\section{Jurnal ELTIKOM : Jurnal Teknik Elektro, Teknologi Informasi dan Komputer}

TABEL 2

RAW DATA ACCELEROMETER.

\begin{tabular}{lcccccccccc}
\hline \hline & I=1 & I=2 & I=3 & I=4 & I=5 & I=6 & I=7 & I=8 & I=9 & I=10 \\
\hline Percobaan1 & 0,285 & 0,289 & 0,287 & 0,291 & 0,290 & 0,287 & 0,286 & 0,287 & 0,285 & 0,285 \\
Percobaan2 & 0,285 & 0,283 & 0,291 & 0,285 & 0,281 & 0,286 & 0,285 & 0,279 & 0,285 & 0,287 \\
Percobaan3 & 0,289 & 0,289 & 0,281 & 0,284 & 0,280 & 0,284 & 0,285 & 0,281 & 0,278 & 0,283 \\
Percobaan4 & 0,281 & 0,277 & 0,283 & 0,279 & 0,281 & 0,284 & 0,279 & 0,281 & 0,281 & 0,283 \\
Percobaan5 & 0,279 & 0,280 & 0,280 & 0,284 & 0,278 & 0,283 & 0,283 & 0,280 & 0,280 & 0,281 \\
Percobaan6 & 0,284 & 0,280 & 0,275 & 0,280 & 0,280 & 0,280 & 0,279 & 0,279 & 0,278 & 0,271 \\
Percobaan7 & 0,273 & 0,277 & 0,271 & 0,273 & 0,279 & 0,277 & 0,278 & 0,275 & 0,280 & 0,280 \\
Percobaan8 & 0,273 & 0,272 & 0,277 & 0,284 & 0,279 & 0,277 & 0,275 & 0,280 & 0,272 & 0,272 \\
Percobaan9 & 0,301 & 0,293 & 0,299 & 0,303 & 0,299 & 0,302 & 0,299 & 0,296 & 0,302 & 0,301 \\
Percobaan10 & 0,302 & 0,304 & 0,299 & 0,305 & 0,298 & 0,303 & 0,302 & 0,301 & 0,297 & 0,303 \\
\hline \hline
\end{tabular}

Tabel 2, menunjukkan untuk melakukan Percobaan 1, nilai pada accelerometer dicatat sebanyak 10 kali dari $i=1$ sampai dengan $i=10$ dengan masing-masing interval pencatatan 1 detik dan dilakukan 10 kali percobaan. Dari semua data percobaan pada Tabel 2, akan dilakukan training dengan cara mengambil nilai selisih perubahan percepatannya dari masing-masing data, dari nilai selisih tersebut ditentukan nilai absolute dengan menggunakan Persamaan 1, seperti yang dilakukan pada Tabel 1.

Berdasarkan Persamaan 1 dilakukan training dan mendapatkan hasil selisih absolute seperti Tabel 3 berikut.

TABEL 3

SELISIH ABSOLUTE HASIL TRAINING RAW DATA PADA BLUETOOTH.

\begin{tabular}{lllllllllll}
\hline \hline & $\mathrm{I}=1$ & $\mathrm{I}=2$ & $\mathrm{I}=3$ & $\mathrm{I}=4$ & $\mathrm{I}=5$ & $\mathrm{I}=6$ & $\mathrm{I}=7$ & $\mathrm{I}=8$ & $\mathrm{I}=9$ & $\mathrm{I}=10$ \\
\hline training1 & 3 & 3 & 3 & 4 & 2 & 2 & 4 & 6 & 6 & 6 \\
training2 & 5 & 6 & 5 & 2 & 4 & 4 & 3 & 5 & 3 & 6 \\
training3 & 4 & 8 & 4 & 2 & 5 & 5 & 1 & 3 & 1 & 8 \\
training4 & 3 & 0 & 1 & 3 & 7 & 3 & 6 & 3 & 1 & 7 \\
training5 & 1 & 5 & 2 & 1 & 4 & 3 & 1 & 1 & 5 & 5 \\
training6 & 3 & 3 & 3 & 4 & 6 & 5 & 0 & 1 & 1 & 6 \\
training7 & 1 & 5 & 2 & 1 & 7 & 5 & 3 & 2 & 2 & 7 \\
training8 & 0 & 4 & 3 & 2 & 1 & 3 & 0 & 5 & 2 & 5 \\
training9 & 7 & 4 & 7 & 3 & 1 & 1 & 1 & 5 & 2 & 7 \\
training10 & 2 & 3 & 2 & 3 & 5 & 1 & 4 & 8 & 7 & 8 \\
\hline \hline
\end{tabular}

Untuk nilai threshold pada silent zone, dipilih nilai selisih yang paling besar dari semua training selama beberapa kali percobaan. Dari contoh data berdasarkan Tabel 3, masing-masing training diambil nilai terbesarnya seperti hasil pada kolom max, kemudian dari kolom max diambil nilai terkecil dan terbesarnya, sehingga didapatkan nilai terkecil adalah 5 dan nilai terbesarnya yaitu 8 .

Tabel 4 untuk nilai threshold pada silent zone, dipilih nilai selisih yang paling besar dari semua training selama beberapa kali percobaan sama yang dilakukan seperti pada Tabel 3. Dari data berdasarkan Tabel 4, masing-masing training diambil nilai terbesarnya seperti hasil pada kolom max, kemudian dari kolom max diambil nilai terkecil dan terbesarnya yaitu 0,00360 dan 0,00839.

Untuk mendapatkan batas bawah dan batas atas dari silent zone untuk Bluetooth dan accelerometer, terlebih dahulu harus mencari standar deviasi dari persebaran datanya.

$$
S^{2}=\frac{\sum_{i=1}^{n} x_{i}^{2}-n \bar{X}^{2}}{n-1}
$$


TABEL 4

SELISIH ABSOLUTE HASIL TRAINING RAW DATA PADA ACCELEROMETER.

\begin{tabular}{|c|c|c|c|c|c|c|c|c|c|c|c|}
\hline & $\mathrm{I}=1$ & $\mathrm{I}=2$ & $\mathrm{I}=3$ & $\mathrm{I}=4$ & $\mathrm{I}=5$ & $\mathrm{I}=6$ & $\mathrm{I}=7$ & $\mathrm{I}=8$ & $\mathrm{I}=9$ & $\mathrm{I}=10$ & MAX \\
\hline training1 & 0,00360 & 0,00121 & 0,00360 & 0,00121 & 0,00240 & 0,00119 & 0,00119 & 0,00240 & 0,00000 & 0,00360 & 0,00360 \\
\hline training2 & 0,00240 & 0,00839 & 0,00600 & 0,00359 & 0,00479 & 0,00121 & 0,00598 & 0,00598 & 0,00240 & 0,00839 & 0,00240 \\
\hline training3 & 0,00000 & 0,00719 & 0,00240 & 0,00360 & 0,00360 & 0,00119 & 0,00359 & 0,00360 & 0,00479 & 0,00719 & 0,00000 \\
\hline training4 & 0,00479 & 0,00598 & 0,00359 & 0,00240 & 0,00240 & 0,00479 & 0,00240 & 0,00000 & 0,00119 & 0,00598 & 0,00479 \\
\hline training5 & 0,00119 & 0,00000 & 0,00360 & 0,00600 & 0,00479 & 0,00000 & 0,00240 & 0,00000 & 0,00121 & 0,00600 & 0,00119 \\
\hline training6 & 0,00360 & 0,00479 & 0,00479 & 0,00000 & 0,00000 & 0,00119 & 0,00000 & 0,00121 & 0,00717 & 0,00717 & 0,00360 \\
\hline training7 & 0,00359 & 0,00598 & 0,00238 & 0,00600 & 0,00240 & 0,00119 & 0,00240 & 0,00479 & 0,00000 & 0,00600 & 0,00359 \\
\hline training8 & 0,00119 & 0,00479 & 0,00719 & 0,00479 & 0,00240 & 0,00121 & 0,00479 & 0,00838 & 0,00000 & 0,00838 & 0,00119 \\
\hline training 9 & 0,00717 & 0,00597 & 0,00360 & 0,00360 & 0,00240 & 0,00240 & 0,00359 & 0,00598 & 0,00119 & 0,00717 & 0,00717 \\
\hline training10 & 0,00240 & 0,00479 & 0,00600 & 0,00719 & 0,00479 & 0,00121 & 0,00119 & 0,00360 & 0,00600 & 0,00719 & 0,00240 \\
\hline
\end{tabular}

di mana, $S^{2}$ adalah nilai varian, $n$ adalah jumlah dari sampel, $i$ adalah index ke $i, x i$ adalah data index ke $i, \bar{X}$ adalah rata-rata. Setelah dilakukan perhitungan standar deviasi $(\sigma)$, selanjutnya ditentukan nilai batas bawah dan batas atas dari silent zone dengan menggunakan rumus Persamaan 3.

$$
\begin{aligned}
& \text { Batas bawah }=\mu-\sigma \\
& \text { Batas atas }=\mu+\sigma
\end{aligned}
$$

di mana, $\mu$ adalah mean dan $(\sigma)$ adalah standar deviasi. Setelah melakukan transformasi nilai batas bawah dan batas atas selanjutnya menggunakan rumus standard scores pada Persamaan 4.

$$
Z=\frac{\chi-\mu}{\sigma}
$$

di mana, $Z$ adalah standard scores, $\chi$ adalah raw score, $\mu$ adalah mean dan $(\sigma)$ adalah standar deviasi. Sehingga didapatkan $Z_{\min }$ dan $Z_{\max }$ yaitu +1 dan -1 . Selanjutnya mencari grafik persebaran probabilitas kumulatifnya dengan rumus Distribusi Gaussian pada Persamaan 5.

$$
f(x)=\frac{1}{\sqrt{2 \pi \sigma^{2}}} e^{-\frac{(x-\mu)^{2}}{2 \sigma^{2}}}
$$

di mana $x$ adalah peubah acak kontinu dan $-\infty \leqslant x \leqslant \infty, \pi$ adalah konstanta dengan nilai 3,14159, $e$ adalah bilangan eksponensial dengan nilai 2,7183, $\mu$ adalah mean dari data dan $(\sigma)$ adalah standar deviasi data.

\section{Experimental Environment}

Eksperimen dilakukan di dalam ruangan kelas dengan total 29 kursi sebagai referensi titik lokasi. Denah lokasi ditunjukkan pada Gambar 4 dengan 3 titik akses WiFi. Sinyal WiFi di lingkungan ini relatif stabil karena ruang yang tidak begitu besar dengan ukuran 8 x 8 meter. Termasuk modul yang terinstal pada perangkat mobile (client), server dan perangkat Bluetooth yang tertancap pada server.

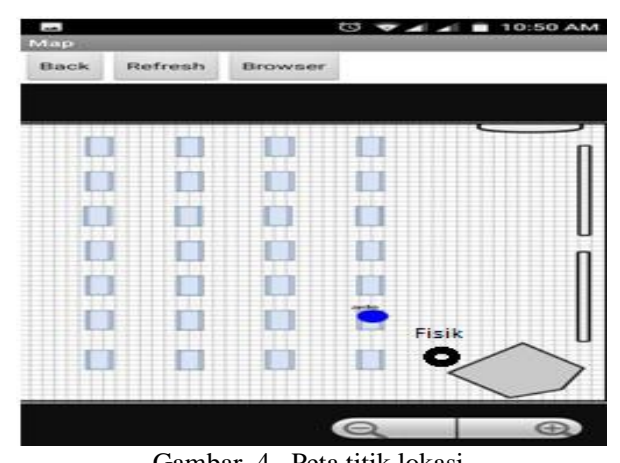

Gambar. 4. Peta titik lokasi. 


\section{Jurnal ELTIKOM : Jurnal Teknik Elektro, Teknologi Informasi dan Komputer}

Modul dalam klien membaca data Bluetooth dan accelerometer sebagai raw data yang akan diolah sebagai silent zone untuk proses scanning secara adaptif, komunikasi dengan server melalui modul HTTP. Smartphone yang digunakan adalah Android A1 dengan spesifikasi seperti pada Tabel 5, spesifikasi Bluetooth pada Tabel 6 dan WiFi router pada Tabel 7.

TABEL 5

SPESIFIKASI SMARTPHONE

\begin{tabular}{cll}
\hline \hline No & PARAMETER & \\
\hline 1 & Sistem Operasi & Android Oreo 8.1 \\
2 & CPU & Octa-core Snapdragon 625 processor, max 2.0GHz, Adreno 506 graphics $650 \mathrm{MHz}$ \\
3 & RAM & $4 \mathrm{~GB}$ \\
4 & Jaringan & $4 \mathrm{G}$, supports volte/4G/3G/2G \\
\hline \hline
\end{tabular}

Tabel 5 menjelaskan bahwa Smartphone dengan spesifikasi sistem operasi Android Oreo 8.1, dengan CPU Octa-core Snapdragon 625 processor, max 2.0GHz, layar dengan Adreno 506 graphics $650 \mathrm{MHz}$, kapasitas RAM 8 GB dan support jaringan untuk 4G, supports volte/4G/3G/2G.

TABEL 6

SPESIFIKASI BLUETOOTH.

\begin{tabular}{lll}
\hline \hline No & \multicolumn{1}{c}{ PARAMETER } & \\
\hline 1 & Interface & USB Dongle \\
2 & Versi & V2.0 \& 1.2 compliant \\
3 & Supporting Profile & Jaringan, Dial-Up, Fax, LAN Access \& Headset \\
4 & Sistem Operasi & Windows 2000, Xp, windows 7/8/10 \\
5 & Symbol Rate & 3 Mbps \\
6 & Jangkauan & $0-100$ meter \\
\hline \hline
\end{tabular}

Tabel 6 menjelaskan bahwa spesifikasi Bluetooth dengan interface berupa USB Dongle dengan versi V2.0 dan 1.2 compliant, support pada jaringan, Dial-Up, Fax, LAN access dan headset. Sistem operasi yang support adalah windows 2000, windows XP/7/8/10 dengan kecepatan 3 Mbps dan jangkauan 0 sampai dengan 100 meter.

TABEL 7

SPESIFIKASI WIFI ROUTER.

\begin{tabular}{|c|c|c|}
\hline No & PARAMETER & SPESIFIKASI \\
\hline 1 & $\mathrm{WiFi}$ router model & TP-Link TL-WR941ND \\
\hline 2 & Chipset & Atheros AR9132@ @ 400 MHz \\
\hline 3 & RAM & $32 \mathrm{MB}$ \\
\hline 4 & Flash & $4 \mathrm{MB}$ \\
\hline 5 & Sistem Operasi & TP-Link \\
\hline 6 & Protocols & IPv4 \\
\hline 7 & Antennas & 3 x 3 dBi RP-SMA \\
\hline 8 & Standards IEEE & $802.11 \mathrm{~b} / \mathrm{g} / \mathrm{n}$ \\
\hline 9 & WAN ports & $1 \times 10 / 100 \mathrm{Mbps}$ \\
\hline 10 & LAN ports & $4 \times 10 / 100 \mathrm{Mbps}$ \\
\hline
\end{tabular}

Tabel 7 menjelaskan bahwa spesifikasi WiFi Router dengan model TP-Link TL-WR941ND dengan chipset Atheros AR9132 @ 400 MHz, kapasitas RAM 32 Mb dengan kapasitas Flash memory 4 Mb, sistem operasi TP-Link. Untuk support protocol IPv4, dengan antenna terdapat 3 buah dengan frekuensi dBi RP-SMA, standard IEEE 802.11 b/g/n, WAN ports dengan kecepatan 1x 10/100 Mbps, Kecepatan LAN ports 4x 10/100 Mbps. 


\section{Jurnal ELTIKOM : Jurnal Teknik Elektro, Teknologi Informasi dan Komputer}

Tahap pertama yang dilakukan untuk pengujian adalah mempersiapkan WiFi router dalam keadaan menyala, selanjutnya Bluetooth berupa USB dongle dalam keadaan tertancap pada PC yang merupakan server dan dalam keadaan menyala. Pengujian yang dilakukan pertama adalah untuk menguji IPS scanning tanpa change detection. Sistem IPS yang sudah terinstal pada Smartphone kemudian dijalankan selama 120 menit dalam kondisi level baterai mulai dari $100 \%$, kemudian dicek penurunan level baterai tiap 10 menit sehingga dihasilkan seperti pada Gambar 5.

Pengujian serupa dilakukan pada IPS scanning dengan change detection menggunakan Bluetooth. Sistem IPS dengan change detection menggunakan Bluetooth yang sudah terinstal pada Smartphone kemudian dijalankan selama 120 menit dalam kondisi level baterai mulai dari 100\%, dengan melakukan skenario pengujian seperti pada Tabel 8 nomor 1 sampai dengan nomor 6 , kemudian dicek penurunan level baterai tiap 10 menit sehingga dihasilkan seperti pada Gambar 6, Gambar 9, Gambar 12, Gambar 15, Gambar 18 dan Gambar 21. Untuk pengujian IPS dengan change detection menggunakan accelerometer tahap pengujiannya sama seperti yang dilakukan pada IPS dengan change detection menggunakan Bluetooth dan menghasilkan pengujian seperti pada Gambar 7, Gambar 10, Gambar 13, Gambar 16, Gambar 19 dan Gambar 22.

Dari pengujian tersebut dijelaskan bahwa IPS dengan mekanisme change detection yang diusulkan dibandingkan dengan IPS tanpa change detection.

\section{1) Level baterai}

Skenario: periode evaluasi adalah 120 menit, tiap 10 menit dilakukan pengecekan perubahan baterai, beberapa skenario pengujian sebagai berikut 1. pengujian dalam kondisi diam 100\%, 2. pengujian $10 \%$ dalam kondisi gerak dari total waktu pengujian, 3. pengujian 30\% dalam kondisi gerak dari total waktu pengujian, 4. pengujian 50\% dalam kondisi gerak dari total waktu pengujian, 5. pengujian 75\% dalam kondisi gerak dari total waktu pengujian, 6. pengujian $100 \%$ dalam kondisi gerak.

2) Akurasi Lokasi

Skenario: periode evaluasi adalah 100 detik, tiap 10 detik dilakukan proses scanning dengan 10 kali percobaan dengan total waktu 100 detik.

\section{HASIL DAN PEMBAHASAN}

Pada bagian ini, membahas tentang hasil efisiensi sumber daya dan akurasi posisi lokasi yang diberikan oleh metode yang dimaksudkan. Penggunaan sumber daya baterai dibandingkan dan diamati dengan menguji dua skenario untuk mengetahui sejauh mana mekanisme change detection bisa berjalan pada sistem seperti yang dirancang sebelumnya.

Pada bagian kedua dari bagian ini akan menjelaskan Analisa, akan membandingkan hasil eksperimen level penggunaan daya baterai dengan enam skenario uji coba masing-masing selama 10 menit pengujian dengan total waktu 120 menit. Pada bagian akhir, akan dibandingkan hasil eksperimen akurasi lokasi dengan interval waktu 10 detik selama 10 pengujian. Keterangan pada Tabel 8 untuk pengujian $10 \%$ gerak artinya pengujian $10 \%$ dalam kondisi gerak untuk pengujian scanning WiFI dan $90 \%$ dalam kondisi diam, sistem tidak melakukan proses scanning. Hal serupa dilakukan pengujian pada nomor 3, 4 dan 5 pada Tabel 8 .

TABEL 8

RINGKASAN HASIL PENGGUNAAN DAYA BATERAI.

\begin{tabular}{llll}
\hline \multirow{3}{*}{ No } & \multirow{2}{*}{ SKENARIO } & \multicolumn{2}{c}{$(\%)$ PENGHEMATAN ENERGI BATERAI } \\
\cline { 3 - 4 } & & BLUETOOTH & ACCELEROMETER \\
\hline \multirow{2}{*}{1} & Pengujian diam 100\% & 4,923 & 7,076 \\
2 & Pengujian 10\% gerak & 4,076 & 5,615 \\
3 & Pengujian 30\% gerak & 3 & 4,769 \\
4 & Pengujian 50\% gerak & 1,538 & 3,615 \\
5 & Pengujian 75\% gerak & 1,384 & 2,692 \\
6 & Pengujian 100\% gerak & 1,076 & 2,538 \\
& & 2,666 & 4,384 \\
\hline \hline
\end{tabular}

Metode yang diusulkan memberikan tingkat penghematan daya baterai rata-rata sebesar 2,666\% untuk 


\section{Jurnal ELTIKOM : Jurnal Teknik Elektro, Teknologi Informasi dan Komputer}

change detection menggunakan Bluetooth dan 4,384\% untuk change detection menggunakan accelerometer dibanding dengan scanning tanpa change detection dengan nilai tetap rata-rata $1,636 \%$. Hasil ringkasan dari pengujian dapat dilihat pada Tabel 8.

Change detection menggunakan accelerometer lebih hemat daya baterai dari penggunaan Bluetooth, karena ketika sistem sedang berjalan pada Smartphone menggunakan Bluetooth ada perangkat tambahan Bluetooth yang harus diaktifkan dibanding dengan accelerometer yang sudah jalan dan tertanam pada Smartphone tanpa harus mengaktifkan perangkat tambahan. Pada accelerometer proses identifikasi perubahan nilainya sangat cepat, sehingga system bisa cepat menentukan proses scanning atau tetap pada kondisi diam.

Hasil dari akurasi lokasi dapat dilihat pada Tabel IX, Tabel X dan Tabel XI. Akurasi lokasi IPS scanning perbandingan antara jarak fisik dan map dihasilkan rata-rata sebesar 1,800 meter, IPS scanning dengan change detection menggunakan Bluetooth perbandingan antara jarak fisik dan map dihasilkan rata-rata sebesar 1,519 meter, IPS scanning dengan change detection menggunakan accelerometer perbandingan antara jarak fisik dan map dihasilkan rata-rata sebesar 1,150 meter.

Analisis pada proses scanning sering terjadi fluktuasi sinyal RSSI pada WiFi yang menentukan keakuratan lokasi. Setiap halangan yang bisa mempengaruhi frekuensi sinyal pada WiFi, harus dihindari. Kendala yang sering terjadi adalah terhalangnya sinyal dengan kondisi dinding pemisah, sehingga mempengaruhi sinyal RSSI untuk menentukan jarak fisik sebenarnya.

TABEL 9

AKURASI POSISI IPS SCANNING

\begin{tabular}{cccc}
\hline \hline $\begin{array}{c}\text { Uji Coba } \\
\text { Ke }\end{array}$ & $\begin{array}{c}\mathrm{X} \\
\text { PADA MAP }\end{array}$ & $\begin{array}{c}\mathrm{y} \\
\text { Pada Map }\end{array}$ & $\begin{array}{c}\text { Jarak Fisik } \\
\text { (Meter) }\end{array}$ \\
\hline 1 & 400 & 400 & 1 \\
2 & 210 & 220 & 2,10 \\
3 & 270 & 106,667 & 2,80 \\
4 & 390 & 220 & 2 \\
5 & 210 & 50 & 3,050 \\
6 & 0 & 0 & 0 \\
7 & 300 & 570 & 0,700 \\
8 & 210 & 220 & 2,100 \\
9 & 210 & 50 & 2 \\
10 & 300 & 135 & 2,250 \\
Rata-rata & & & 1,800 \\
\hline \hline
\end{tabular}

Tabel 9 menjelaskan bahwa lokasi titik koordinat $(x=400, y=400)$, setelah dilakukan training selama 10 kali dengan interval eksekusi masing-masing selama 10 detik menghasilkan jarak secara fisik sebesar 1,800 meter dengan IPS scanning periodik dengan delay 3 detik.

TABEL 10

AKURASI Posisi IPS SCANNING DENGAN CHANGE DETECTION MENGGUNAKAN BLUETOOTH.

\begin{tabular}{cccc}
\hline \hline $\begin{array}{c}\text { Uji Coba } \\
\text { Ke }\end{array}$ & $\begin{array}{c}\mathrm{X} \\
\text { PADA MAP }\end{array}$ & $\begin{array}{c}\mathrm{y} \\
\text { Pada Map }\end{array}$ & $\begin{array}{c}\text { Jarak Fisik } \\
\text { (Meter) }\end{array}$ \\
\hline 1 & 400 & 400 & 1 \\
2 & 300 & 570 & 0,700 \\
3 & 210 & 135 & 2,070 \\
4 & 210 & 135 & 2,070 \\
5 & 300 & 570 & 0,700 \\
6 & 300 & 570 & 0,700 \\
7 & 30 & 570 & 2 \\
8 & 300 & 570 & 0,700 \\
9 & 120 & 50 & 3,150 \\
10 & 210 & 135 & 2,100 \\
Rata-rata & & & 1,519 \\
\hline \hline
\end{tabular}

Tabel 10 menjelaskan pada lokasi titik koordinat $(x=400, y=400)$, setelah dilakukan training selama 10 kali dengan interval waktu masing-masing 10 detik, menghasilkan jarak secara fisik sebesar 1,519 meter dengan IPS change detection menggunakan Bluetooth. 


\section{Jurnal ELTIKOM : Jurnal Teknik Elektro, Teknologi Informasi dan Komputer}

TABEL 11

\begin{tabular}{|c|c|c|c|}
\hline $\begin{array}{c}\text { Uji Coba } \\
\mathrm{Ke}\end{array}$ & $\begin{array}{c}\mathrm{X} \\
\text { PADA MAP }\end{array}$ & $\begin{array}{c}\text { y } \\
\text { Pada Map }\end{array}$ & $\begin{array}{c}\text { Jarak Fisik } \\
\text { (Meter) }\end{array}$ \\
\hline 1 & 400 & 400 & 1 \\
\hline 2 & 240 & 106,67 & 2,850 \\
\hline 3 & 0 & 0 & 0 \\
\hline 4 & 210 & 135 & 2,100 \\
\hline 5 & 255 & 440 & 0,900 \\
\hline 6 & 210 & 310 & 1,150 \\
\hline 7 & 300 & 570 & 0,700 \\
\hline 8 & 300 & 570 & 0,700 \\
\hline 9 & 0 & 0 & 0 \\
\hline 10 & 210 & 135 & 2,100 \\
\hline Rata-rata & & & 1,150 \\
\hline
\end{tabular}

Tabel 11 menjelaskan untuk lokasi titik koordinat $(x=400, y=400)$, setelah dilakukan training selama 10 kali dengan interval waktu masing-masing 10 detik menghasilkan jarak secara fisik sebesar 1,150 meter dengan IPS change detection menggunakan accelerometer. Hasil ringkasan dari ketiga uji coba di dapatkan jarak secara fisik rata-rata sebesar 1,490 meter. Perincian rata-rata tersebut secara detail sebagai berikut, IPS sebesar 1,800 meter dan Bluetooth sebesar 1,519 meter. Keterangan pada Tabel 3, Tabel 4 dan Tabel 5 ilustrasi lokasinya bisa dilihat pada Gambar 4 yang menggambarkan letak lokasi secara fisik dan koordinat map.

\section{IPS Scanning Tanpa Change Detection}

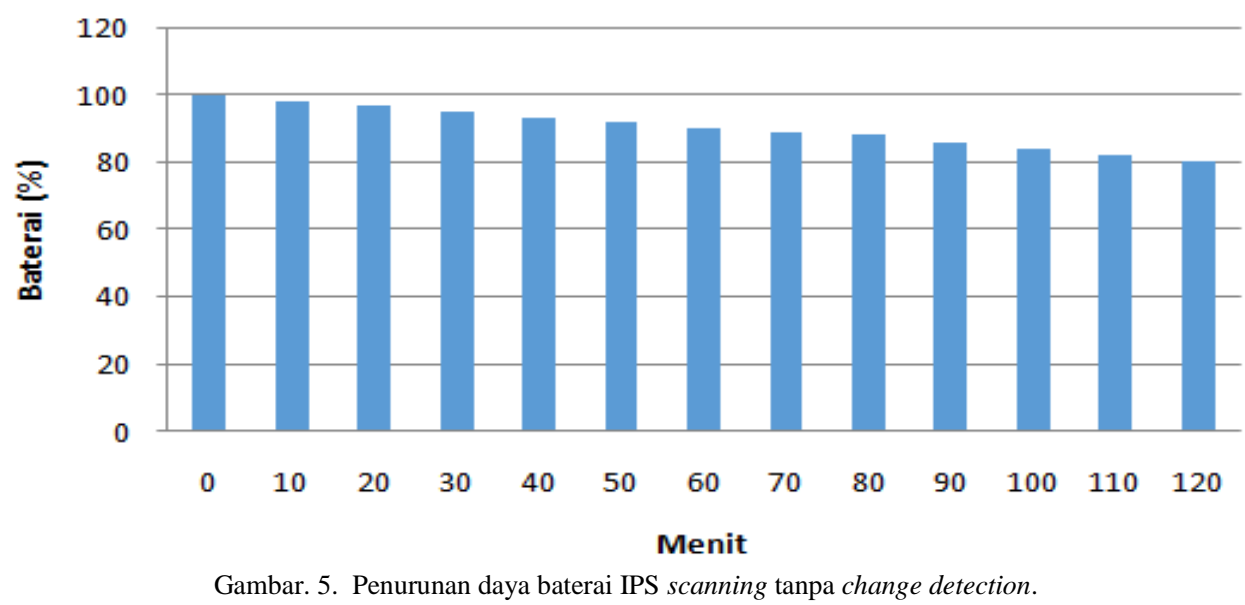

Gambar 5 menjelaskan bahwa proses pengujian scanning tanpa adanya proses change detection.

Change Detection Bluetooth Kondisi Diam 100\%

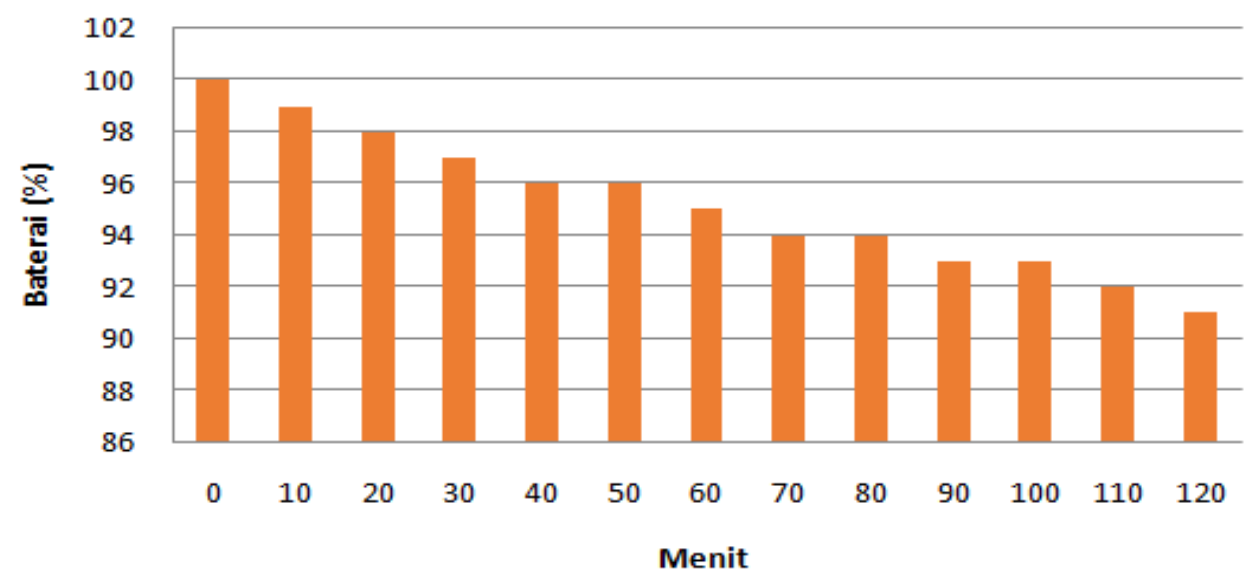

Gambar. 6. Penurunan daya baterai kondisi diam 100\% dengan Bluetooth. 


\section{Jurnal ELTIKOM : Jurnal Teknik Elektro, Teknologi Informasi dan Komputer}

\section{Change Detection Accelerometer Kondisi Diam 100\%}

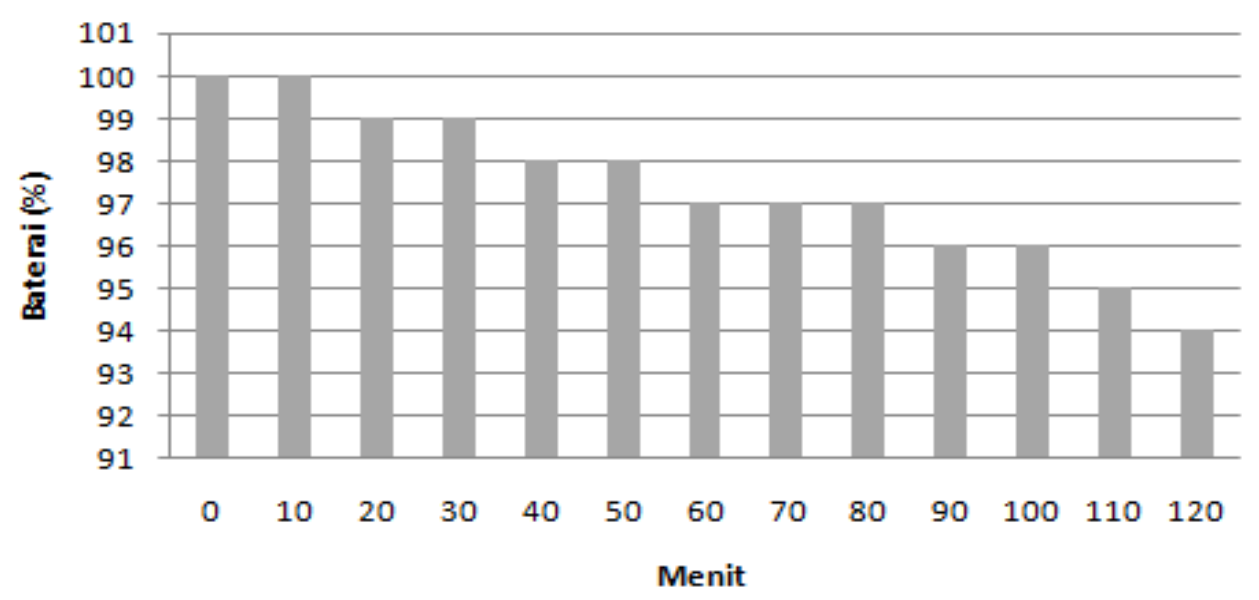

Gambar. 7. Penurunan daya baterai kondisi diam $100 \%$ dengan accelerometer.

\section{Level Baterai Kondisi Diam 100\%}

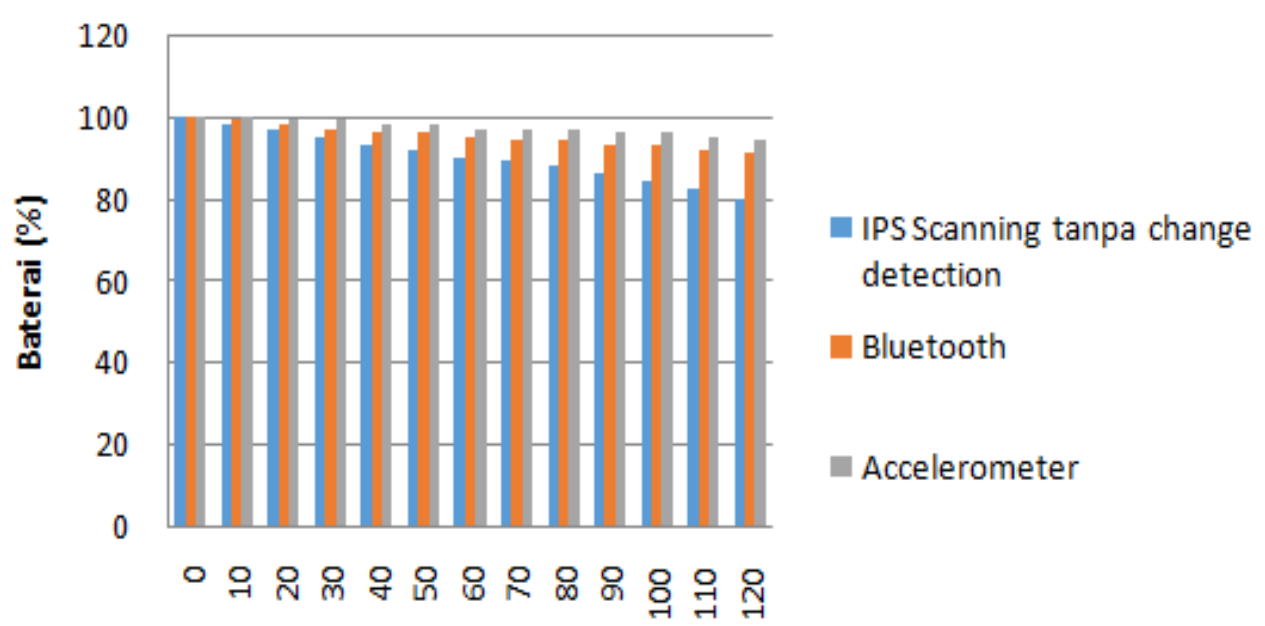

Menit

Gambar. 8. Perbandingan penurunan daya baterai kondisi diam 100\% dengan IPS scanning.

Gambar 8 didapatkan penghematan energi baterai sebesar 4,923\% dengan change detection menggunakan Bluetooth dan 7,076\% dengan menggunakan accelerometer.

Change Detection Bluetooth Kondisi Gerak 10\%

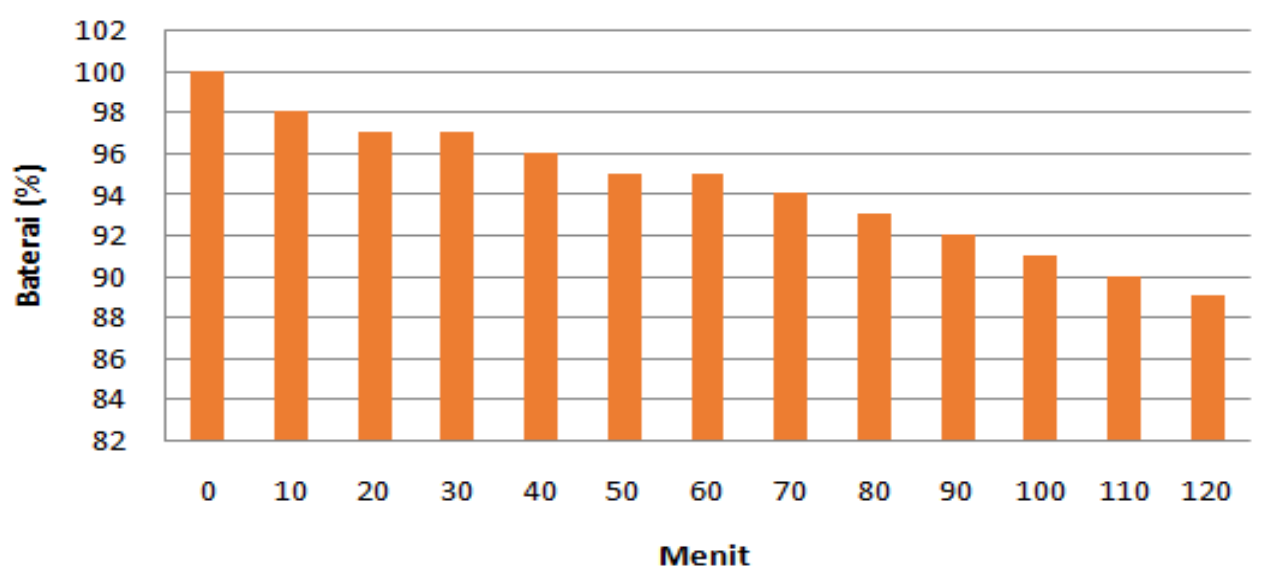

Gambar. 9. Penurunan daya baterai kondisi gerak 10\% dengan Bluetooth. 


\section{Jurnal ELTIKOM : Jurnal Teknik Elektro, Teknologi Informasi dan Komputer}

Change Detection Accelerometer Kondisi Gerak 10\%

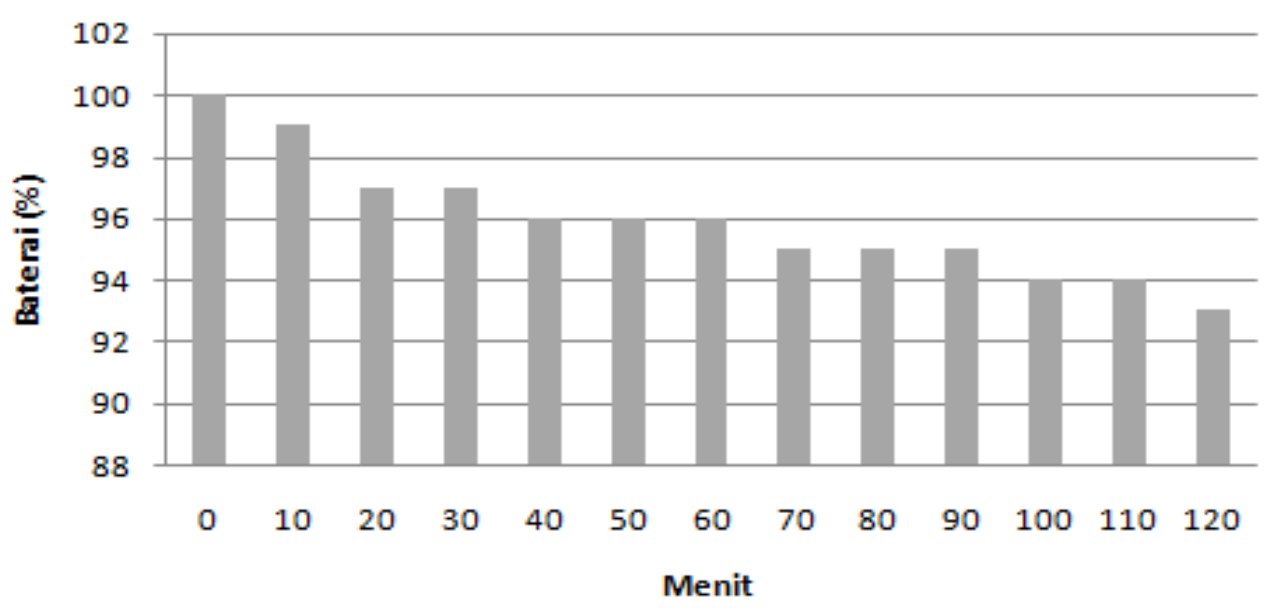

Gambar. 10. Penurunan daya baterai kondisi gerak 10\% dengan accelerometer.

\section{Level Baterai Kondisi Gerak 10\%}

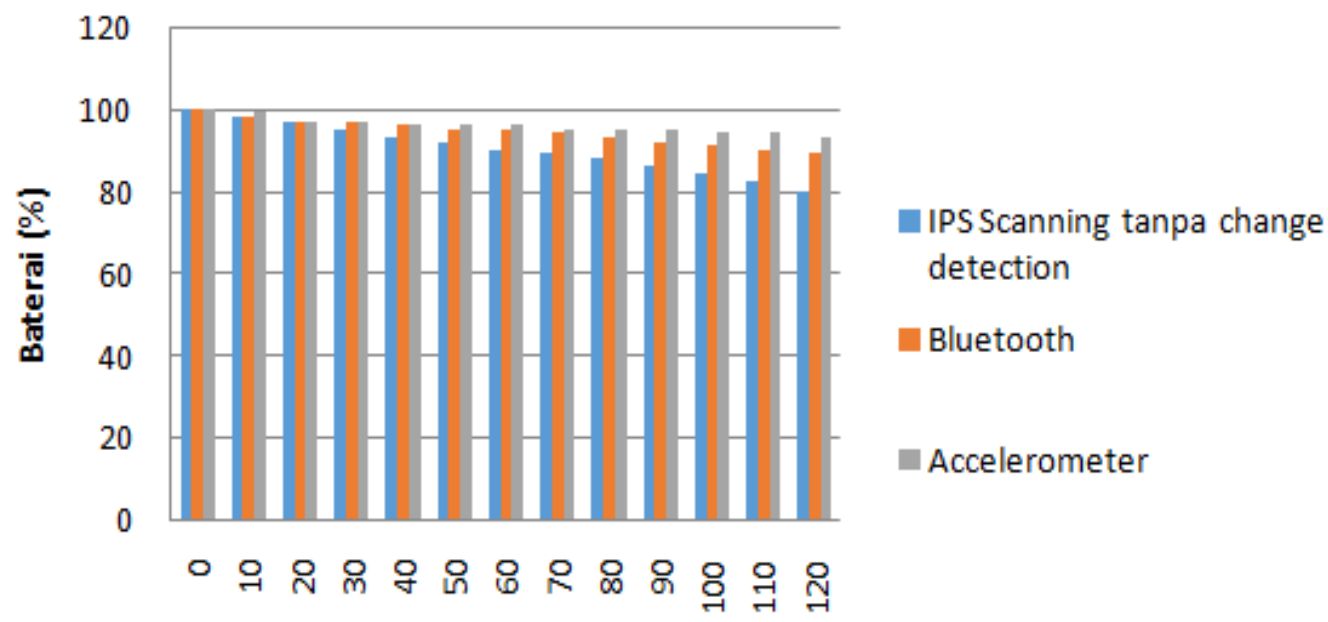

Menit

Gambar. 11. Perbandingan penurunan daya baterai kondisi gerak $10 \%$ dengan IPS periodik.

Gambar 11 didapatkan penghematan energi baterai sebesar 4,076\% dengan change detection menggunakan Bluetooth dan 5,615\% dengan menggunakan accelerometer.

Change Detection Bluetooth Kondisi Gerak 30\%

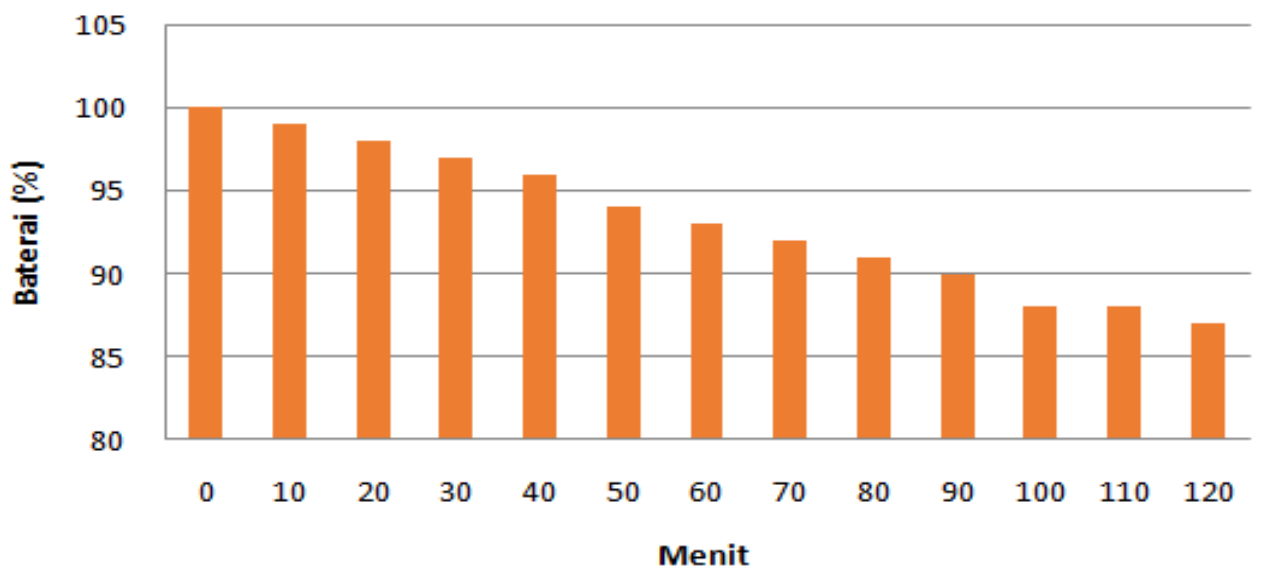

Gambar. 12. Penurunan daya baterai kondisi gerak 30\% dengan Bluetooth. 


\section{Jurnal ELTIKOM : Jurnal Teknik Elektro, Teknologi Informasi dan Komputer}

Change Detection Accelerometer Kondisi Gerak 30\%

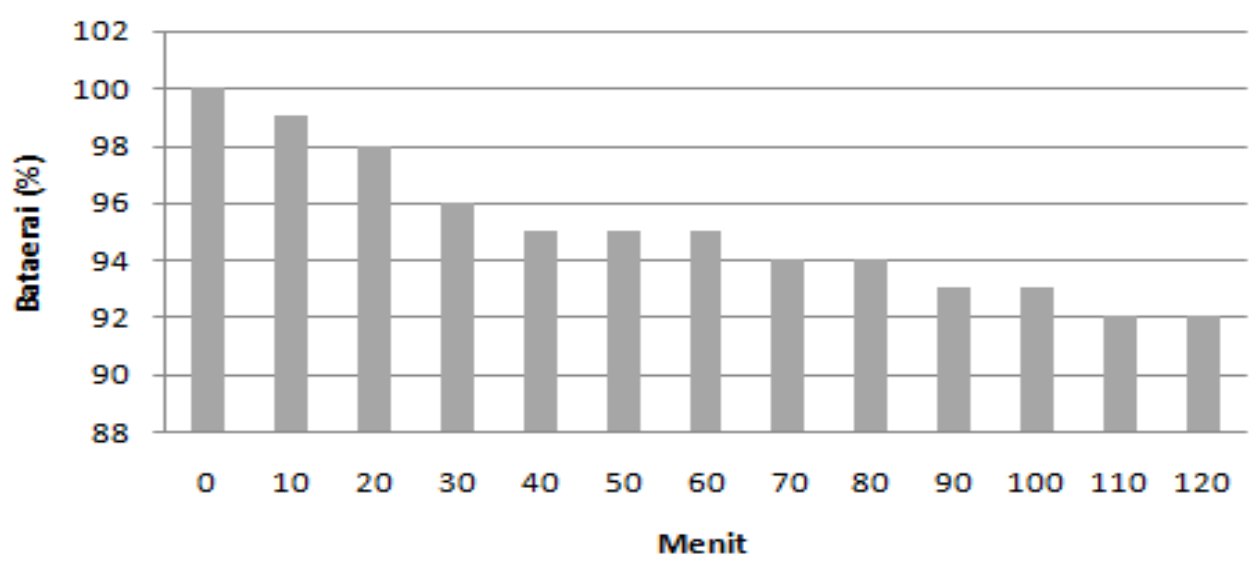

Gambar. 13. Penurunan daya baterai kondisi gerak 30\% dengan accelerometer.

\section{Level Baterai Kondisi Gerak 30\%}

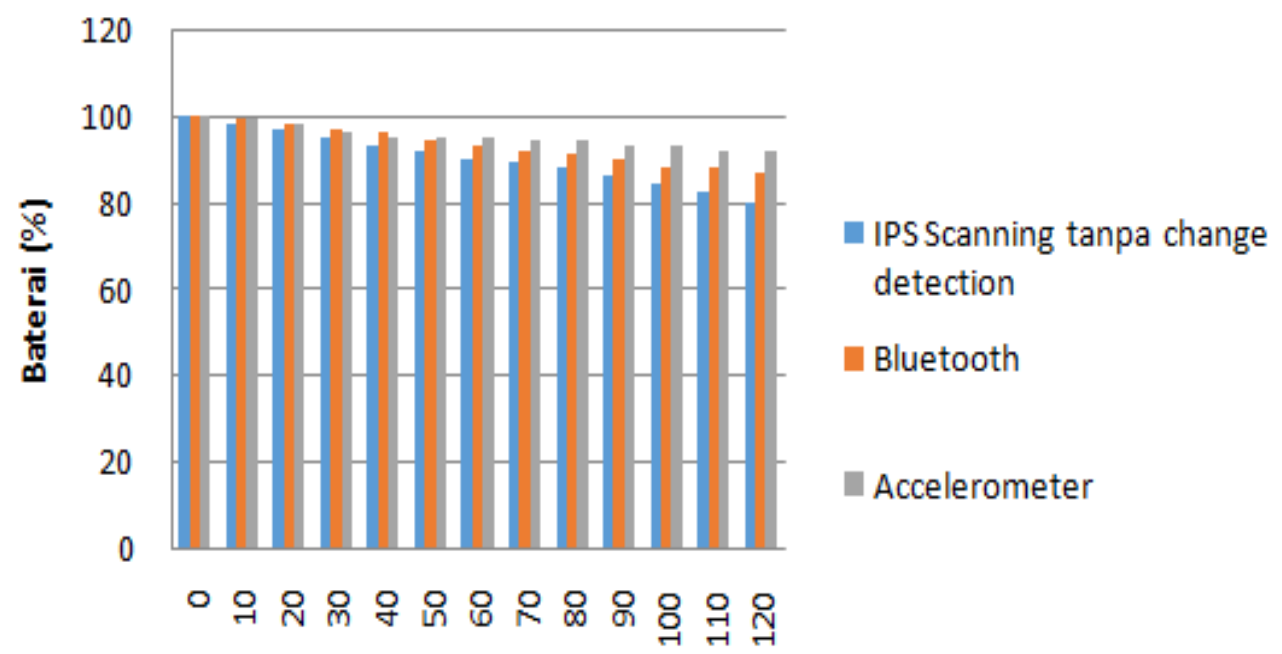

\section{Menit}

Gambar. 14. Perbandingan penurunan daya baterai kondisi gerak 30\% dengan IPS periodik.

Gambar 14 pengujian dalam kondisi gerak 30\% didapatkan penghematan energi baterai sebesar 3\% dengan change detection menggunakan Bluetooth dan 4,769\% dengan menggunakan accelerometer.

\section{Change Detection Bluetooth Kondisi Gerak 50\%}

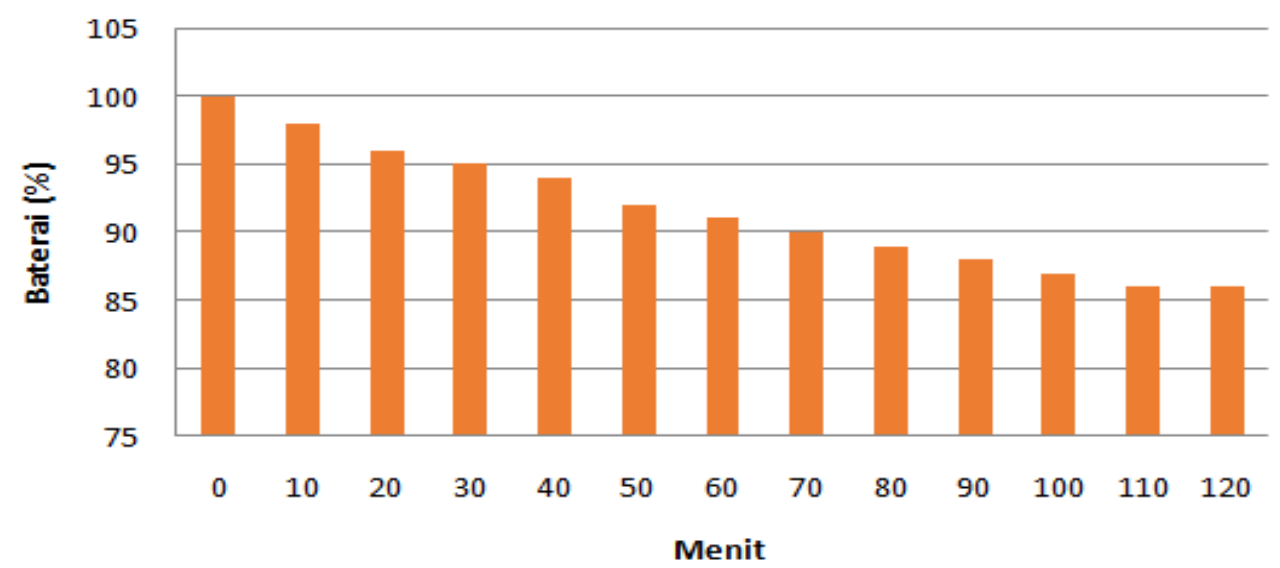

Gambar. 15. Penurunan daya baterai kondisi gerak 50\% dengan Bluetooth. 


\section{Jurnal ELTIKOM : Jurnal Teknik Elektro, Teknologi Informasi dan Komputer}

\section{Change Detection Accelerometer Kondisi Gerak 50\%}

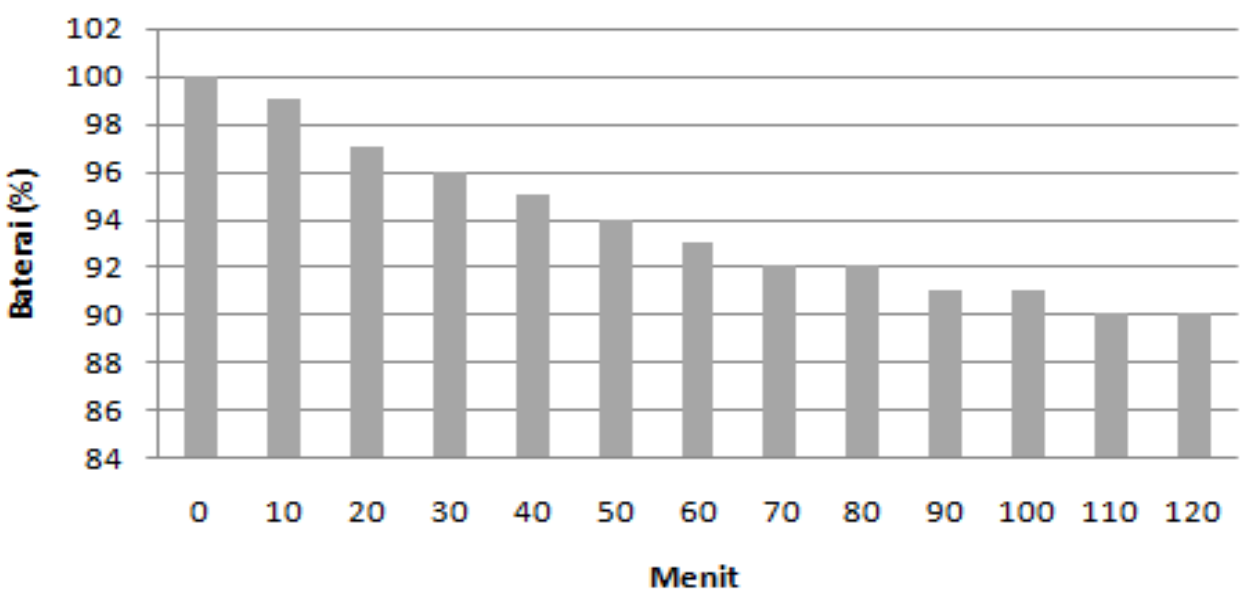

Gambar. 16. Penurunan daya baterai kondisi gerak 50\% dengan accelerometer.

\section{Level Baterai Kondisi Gerak 50\%}

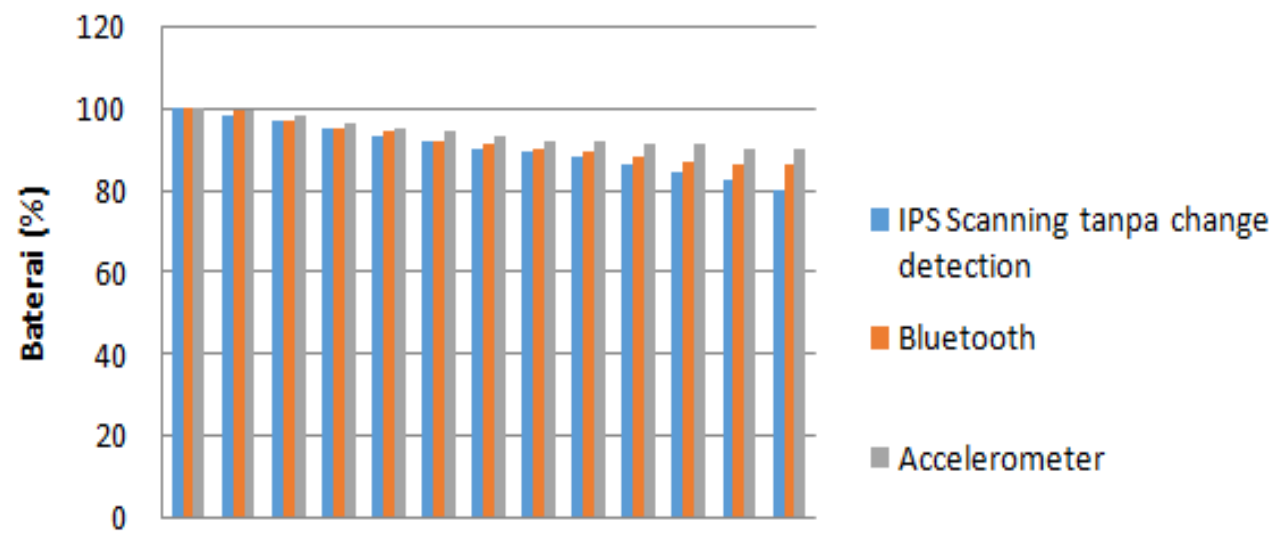

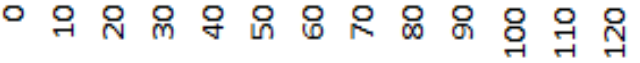

Menit

Gambar. 17. Perbandingan penurunan daya baterai kondisi gerak 50\% dengan IPS periodik.

Gambar 17 pengujian dalam kondisi gerak 50\% didapatkan penghematan energi baterai sebesar 1,538\% dengan change detection menggunakan Bluetooth dan 3,615\% dengan menggunakan accelerometer.

Change Detection Bluetooth Kondisi Gerak 75\%

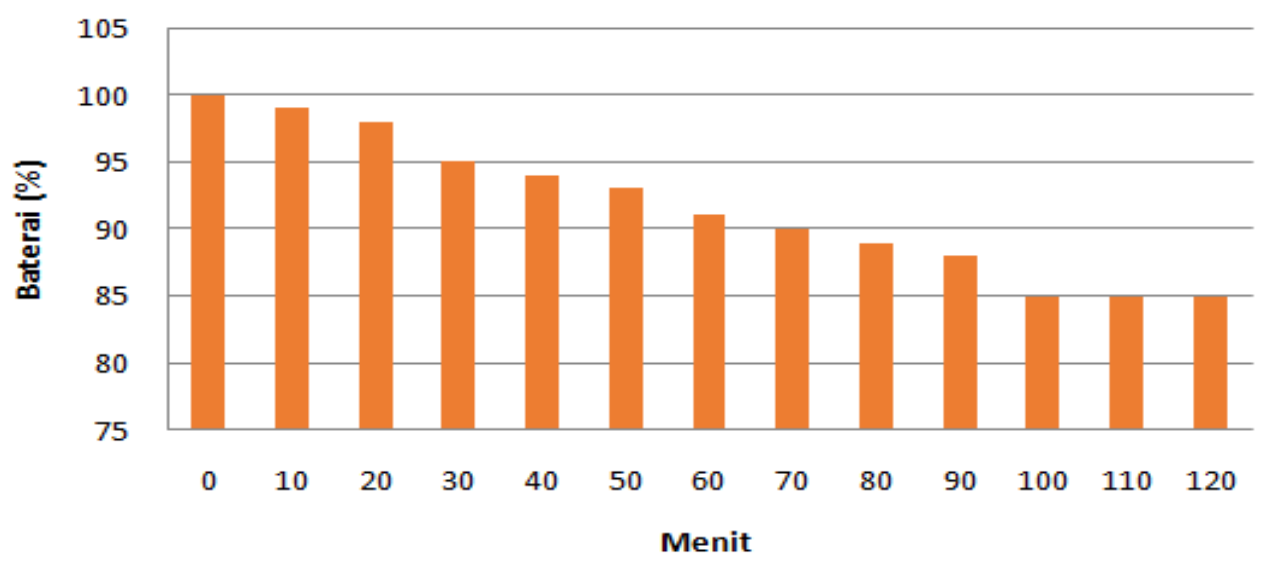

Gambar. 18. Penurunan daya baterai kondisi gerak $75 \%$ dengan Bluetooth. 


\section{Jurnal ELTIKOM : Jurnal Teknik Elektro, Teknologi Informasi dan Komputer}

\section{Change Detection Accelerometer Kondisi Gerak 75\%}

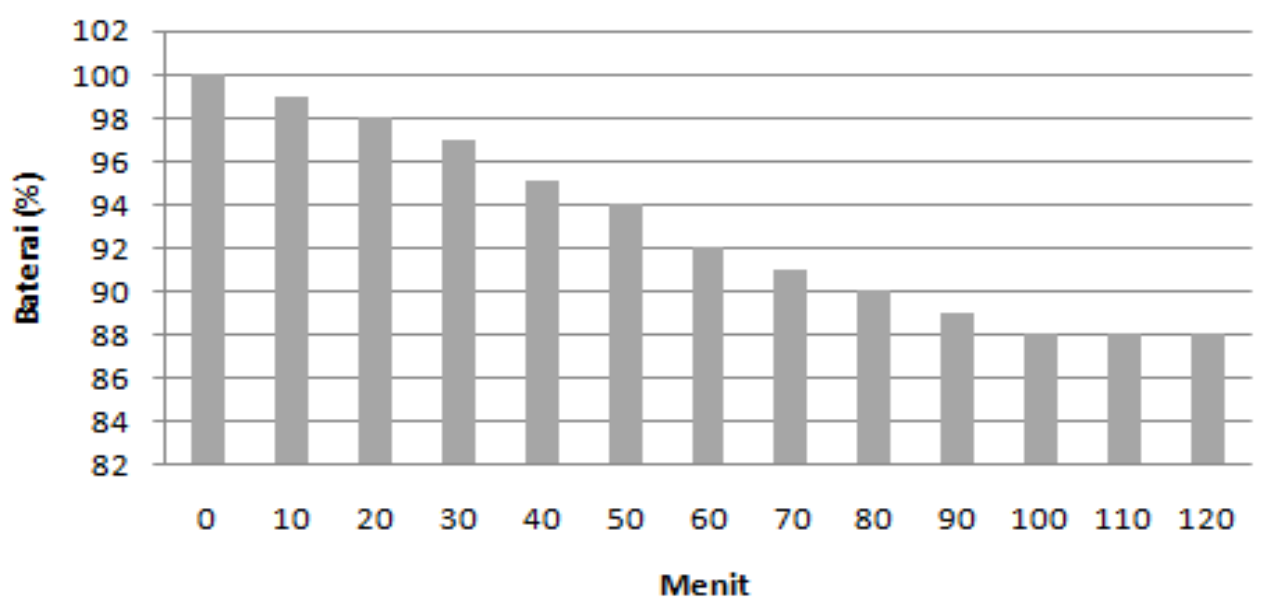

Gambar. 19. Penurunan daya baterai kondisi gerak 75\% dengan accelerometer.

\section{Level Baterai Kondisi Gerak 75\%}

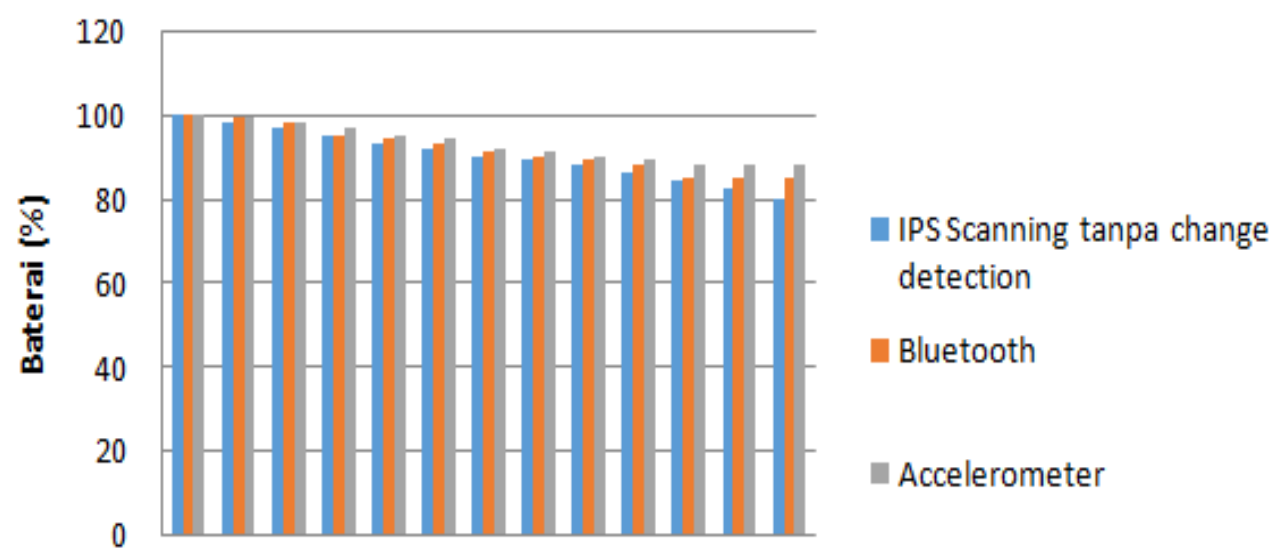

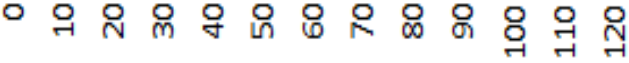

Menit

Gambar. 20. Perbandingan penurunan daya baterai kondisi gerak $75 \%$ dengan IPS periodik.

Gambar 20 pengujian dalam kondisi gerak $75 \%$ didapatkan penghematan energi baterai sebesar $1,384 \%$ dengan change detection menggunakan Bluetooth dan 2,692\% dengan menggunakan accelerometer.

Change Detection Bluetooth Kondisi Gerak 100\%

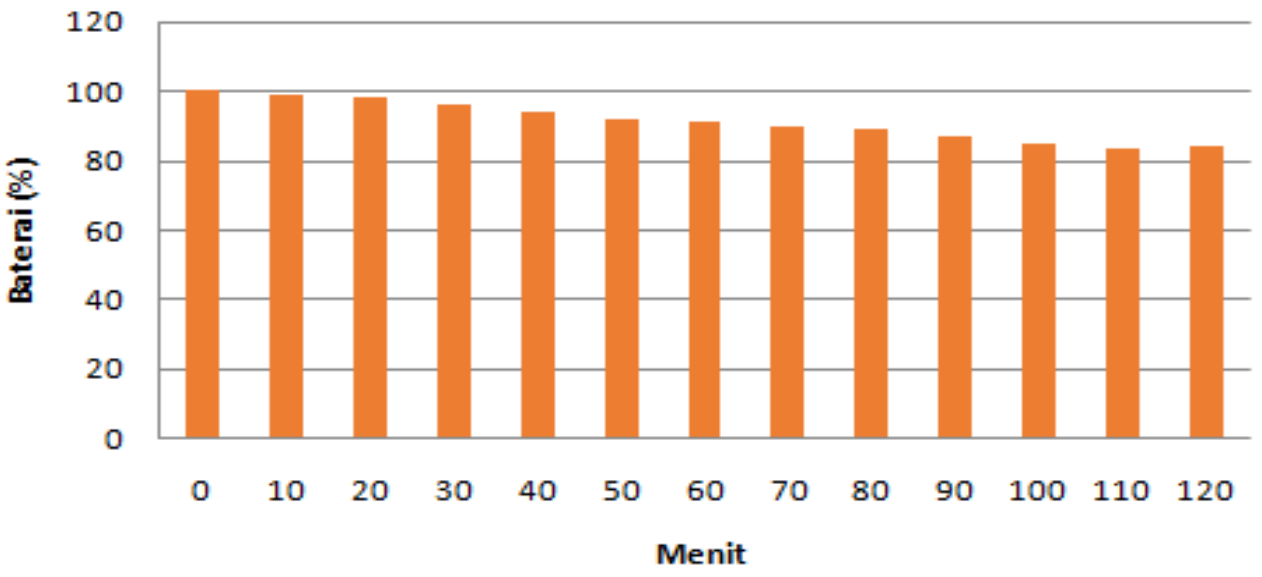

Gambar. 21. Penurunan daya baterai kondisi gerak 100\% dengan Bluetooth. 


\section{Jurnal ELTIKOM : Jurnal Teknik Elektro, Teknologi Informasi dan Komputer}

Change Detection Accelerometer Kondisi Gerak 100\%

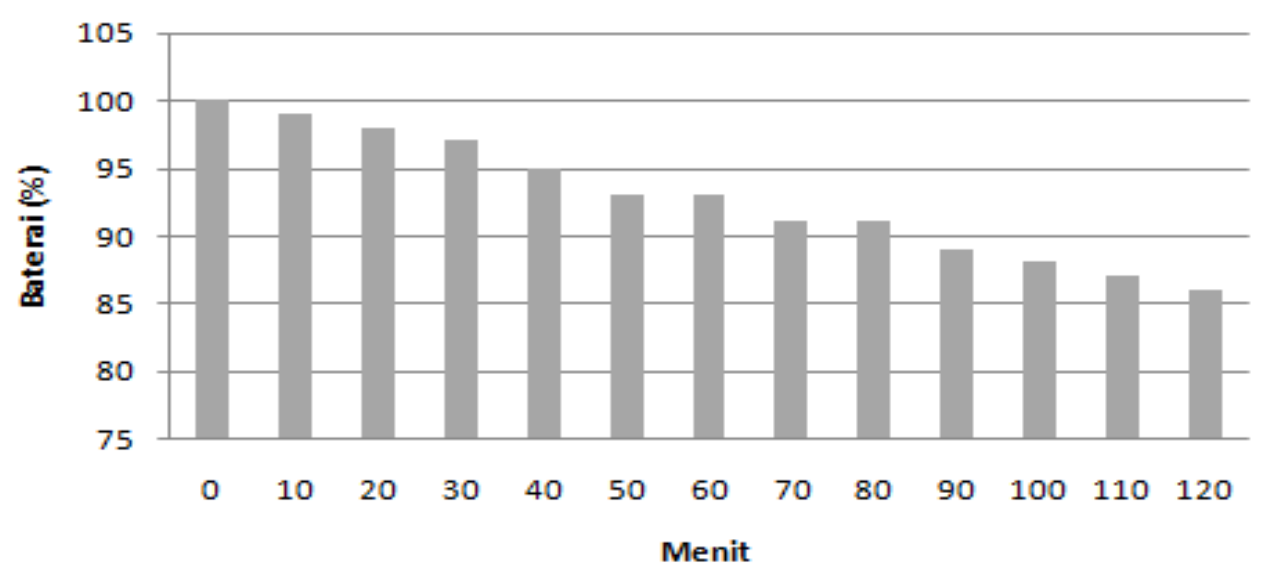

Gambar. 22. Penurunan daya baterai kondisi gerak 100\% dengan accelerometer.

\section{Level Baterai Kondisi Gerak 100\%}

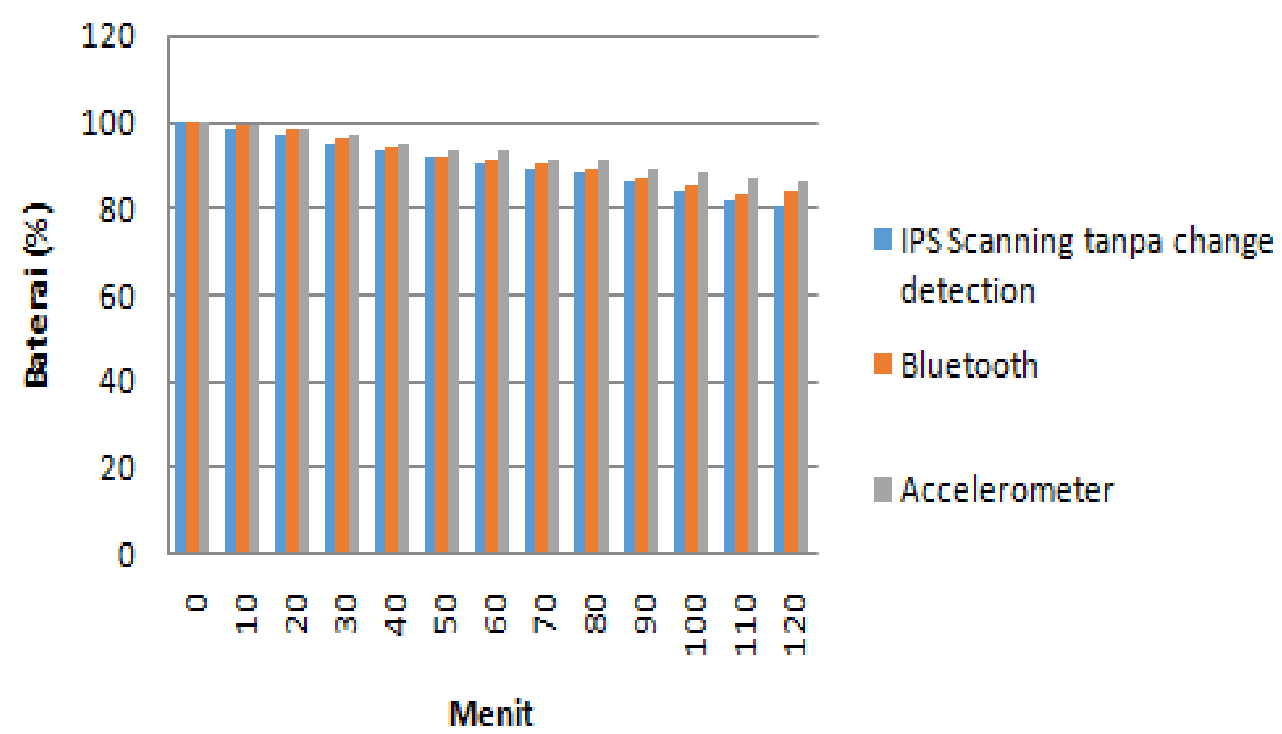

Gambar. 23. Perbandingan penurunan daya baterai kondisi gerak $100 \%$ dengan IPS periodik.

Gambar 23 pengujian dalam kondisi gerak 100\% didapatkan penghematan energi baterai sebesar 1,076\% dengan change detection menggunakan Bluetooth dan 2,538\% dengan menggunakan accelerometer.

\section{KesIMPULAN}

Hasil uji coba menunjukkan bahwa pendekatan mekanisme change detection yang diusulkan dapat meningkatkan efisiensi energi pada IPS. Mekanisme change detection berbasis accelerometer dapat menghemat energi hingga 4,38\%, sedangkan mekanisme change detection berbasis Bluetooth hanya mampu menghemat energi sampai 2,66\% dibandingkan dengan teknik scanning tanpa change detection.

Pada sistem pengembangan mekanisme change detection ini memiliki kekurangan mengenai masalah responsif, terutama menggunakan Bluetooth ketika untuk mengidentifikasi kondisi bergerak dari posisi diam, pada Bluetooth harus menunggu selesai terlebih dahulu proses sampling untuk menentukan nilai silent zone, karena berpengaruh pada penghematan energi. Pada Bluetooth ketika menyimpan satu data ada jeda beberapa detik pada satu data berikutnya. Perlu dilakukan penelitian lebih lanjut terhadap Bluetooth agar bisa responsif seperti pada accelerometer. 
DAFTAR PUSTAKA

[1] J. Niu, B. Wang, L. Shu, T. Q. Duong, and Y. Chen, "ZIL: An Energy-Efficient Indoor Localization System Using ZigBee Radio to Detect WiFi Fingerprints," IEEE J. Sel. Areas Commun., vol. 33, no. 7, pp. 1431-1442, 2015

[2] W. Waqar, Y. Chen, and A. Vardy, "Smartphone positioning in sparse Wi-Fi environments," Comput. Commun., vol. 73, pp. 108-117, 2016.

[3] X. Du, "Map-assisted Indoor Positioning Utilizing Ubiquitous WiFi Signals," no. February, 2018.

[4] X. Y. Liu, S. Aeron, V. Aggarwal, X. Wang, and M. Y. Wu, "Adaptive Sampling of RF Fingerprints for Fine-Grained Indoor Localization," IEEE Trans. Mob. Comput., vol. 15, no. 10, pp. 2411-2423, 2016.

[5] T.; S. T. Sugino, Kyohei ; Niwa, Yusuke; Shiramatsu, Shun; Ozono, "Developing a Human Motion Detector using Bluetooth Beacons and its Applications," Inf. Eng. Express, vol. 1, no. 4, p. PP.95-105, 2015.

[6] A. Lourenço et al., "Activity Recognition from Accelerometer Data on a Mobile Phone," Distrib. Comput. Artif. Intell. Bioinformatics, Soft Comput. Ambient Assist. Living, vol. 5518, no. June 2009, pp. 954-963, 2009.

[7] D. M. Karantonis, M. R. Narayanan, M. Mathie, N. H. Lovell, and B. G. Celler, "Implementation of a real-time human movement classifier using a triaxial accelerometer for ambulatory monitoring," IEEE Trans. Inf. Technol. Biomed., vol. 10, no. 1, pp. 156-167, 2006.

[8] M. J. Mathie, A. C. F. Coster, N. H. Lovell, B. G. Celler, S. R. Lord, and A. Tiedemann, "A pilot study of long-term monitoring of human movements in the home using accelerometry," J. Telemed. Telecare, vol. 10, no. 3, pp. 144-151, 2004.

[9] M. A. Hoque, M. Siekkinen, and J. K. Nurminen, "Energy Efficient Multimedia Streaming to Mobile Devices - A Survey," no. March, 2014.

[10] H. Sajid and A. Al, "Indoor navigation to estimate energy consumption in android platform," vol. 3, no. 1, pp. 32-36, 2018.

[11] Y. U. Gu, F. Ren, and S. Member, "Energy-Efficient Indoor Localization of Smart Hand-Held Devices Using Bluetooth," vol. 3, 2015

[12] J. Tuta and M. B. Juric, "A self-adaptive model-based Wi-Fi indoor localization method," Sensors (Switzerland), vol. 16, no. $12,2016$.

[13] N. Vallina-rodriguez, P. Hui, J. Crowcroft, and A. Rice, "Exhausting Battery Statistics," no. February, pp. 9-14, 2010.

[14] H. Sajid and A. Al, "Indoor navigation to estimate energy consumption in android platform," vol. 3, no. 1, pp. 32-36, 2018.

[15] A. Alvarez-Alvarez, J. M. Alonso, and G. Trivino, "Human activity recognition in indoor environments by means of fusing information extracted from intensity of WiFi signal and accelerations," Inf. Sci. (Ny)., vol. 233, no. June, pp. 162-182, 2013.

[16] D. Aiordachioaie, "On quick-change detection based on process adaptive modelling and identification," 2014 Int. Conf. Dev. Appl. Syst. DAS 2014 - Conf. Proc., pp. 25-28, 2014.

[17] T. Duc-tan, N. Dinh-chinh, T. Duc-nghia, and T. Duc-tuyen, "Development of a Rainfall-Triggered Landslide System using Wireless Accelerometer Network," vol. 7, no. September, pp. 14-24, 2015.

[18] S. S. Ho and H. Wechsler, "A Martingale framework for detecting changes in data streams by testing exchangeability," IEEE Trans. Pattern Anal. Mach. Intell., vol. 32, no. 12, pp. 2113-2127, 2010.

[19] D. Aiordachioaie, "On quick-change detection based on process adaptive modelling and identification," 2014 Int. Conf. Dev. Appl. Syst. DAS 2014 - Conf. Proc., pp. 25-28, 2014.

[20] A. Ahrabian, T. Elsaleh, Y. Fathy, and P. Barnaghi, "Detecting changes in the variance of multi-sensory accelerometer data using MCMC," Proc. IEEE Sensors, vol. 2017-Decem, pp. 1-3, 2017.

[21] D. Aiordachioaie, "On quick-change detection based on process adaptive modelling and identification,” 2014 Int. Conf. Dev. Appl. Syst. DAS 2014 - Conf. Proc., pp. 25-28, 2014.

[22] L. I. Kuncheva, "Change detection in streaming multivariate data using likelihood detectors," IEEE Trans. Knowl. Data Eng., vol. 25, no. 5, pp. 1175-1180, 2013.

[23] R. Sebastião and J. Gama, "Change detection in learning histograms from data streams," Lect. Notes Comput. Sci. (including Subser. Lect. Notes Artif. Intell. Lect. Notes Bioinformatics), vol. 4874 LNAI, no. December, pp. 112-123, 2007.

[24] Y. Wang, X. Yang, Y. Zhao, Y. Liu, and L. Cuthbert, "Bluetooth positioning using RSSI and triangulation methods," 2013 IEEE 10 th Consum. Commun. Netw. Conf. CCNC 2013, pp. 837-842, 2013.

[25] W. Sri Indrawanti, Annisaa; Wibisono, "A Change Detection And Resource - Aware Data Sensing Approaches For Improving The Reporting Protocol Mechanism For Mobile User,”vol. 2, pp. 92-99, 2015. 